\title{
Is the city the appropriate scale for participatory democracy? Some answers from Brazil
}

\author{
Sveinung Legard
}

The city used to have a prominent place in political theory, but as the nation-state became the dominant political form in the 18th century, the city largely disappeared from political philosophy (Dahl and Tufte 1973, chapter 1). Nevertheless, the city lingered on in democratic theory, especially among thinkers who criticized representative government and maintained that some kind of participatory politics should be put in its place. Two of the most outspoken bearers of this tradition are Murray Bookchin and Benjamin Barber. They see the city as a potential realm of the citizens' collective management through face-to-face assemblies (Bookchin 1995), and as a natural venue for citizen participation (Barber 2013). Even Robert Dahl, considered by some the father of modern political science, argues that the medium-sized city is the optimal unit for democracy: it is both big enough to deal with the most vital aspects of our environment, yet at the same time small enough for citizens to participate extensively in determining the ways in which power should be used (Dahl 1967; Dahl 1990, 126-135).

City-democrats like these do not present empirical theories that can be tested through observation and experiment. They make normative claims of what democracy should be like. Nonetheless, their claims are based on assumptions of the viability and achievability of the alternatives they present, which in turn are informed by empirical cases (Wright 2010, 21-25). Some of the historical examples they use include classical Athens, city republics in medieval Italy, or rebellious cities like Paris during the Great French Revolution. The contemporary case probably most used to support the city democratic view, is participatory budgeting in Brazil (Pateman 2012). There, municipalities have given citizens the opportunity to decide the budget through an open, participatory 
process. Archon Fung has written that the significance of participatory budgeting for the theory of participatory democracy is akin to the discovery of the quark in theoretical physics (Fung 2011, 859).

One way to think of such empirical examples is that they constitute one of many building blocks or 'provisional fixed points' of normative theories. Both these points and the general theory itself are open to continual revisions, and if the points are incompatible with the general normative theory, we might consider either revising the fixed point or the theory, or vice versa (Thacher 2006, 1647-1648). I doubt that any city democrats would discard their view if participatory budgeting in Brazil did not turn out to be as good as many think, but it could spark revisions of their theories. The fixed point that I will discuss in this article is the assumption that the city is a more appropriate scale for participatory democracy than higher levels of government. Barber relates this directly to participatory budgeting. He writes that participatory budgeting cannot prove that urban government is more capable of 'strong democracy' than the state, but it at least "offers hope for those who believe there may be a little less distance between mayors and citizens than between voters and state authorities" (Barber 2013, 308). I ask whether the experience of participatory budgeting in Brazil warrants this hope. Does participatory budgeting work better at the city level than at larger scales? And what does this tell us about the assumption that the city is the appropriate scale for participatory democracy?

In this article I compare participatory budgeting in the city of Porto Alegre (a city with about 1.5 million inhabitants) and the state of Rio Grande do Sul in southern Brazil (a state with about 11.2 million inhabitants). This limits the scope of the answer. I do not, for example, compare participatory processes at the municipal and the federal level. I also eschew comparisons such as those between the city and the countryside, between cities of different sizes, or of the type of conditions that promote or impede participatory processes at different levels. These are undoubtedly important for a broader evaluation of the city as a site for participatory democracy, but are not the focus here. Notwithstanding these limitations, the comparison in this study provides a partial but interesting answer. Even though the practice of participatory budgeting more closely resembles ideals of participatory democracy at the city level, it does not mean that participatory democracy is impossible at larger scales. On the contrary, the difference between participatory budgeting at the city and state level is more a question of grades than leaps in 
terms of democratic qualities. Furthermore, some of the features that are considered unique to the city - neighborhood-based community associations that mobilize and discuss with citizens in local public spheres - are also important in participatory budgeting at the state level. The experiences of participatory budgeting at the city and state level in Brazil suggests that it is both wrong to overemphasize the uniqueness of the city as well as to downplay the possibility that it might play a special role in both local and larger participatory processes.

\section{Participatory democracy and the city}

There exists a diversity of versions of 'participatory democracy' (see for example Pateman 1970; Mansbridge 1983; Bachrach and Botwinick 1992; della Porta 2013). Most define it as a type of organization (here a form of government) that is based on the direct participation in decision-making processes by those that are affected by such decisions. These processes have to possess real decision-making powers, and empower previously excluded and marginalized groups. A participatory democracy does not exclude the election of some individuals to perform certain tasks or take certain decisions, but it shifts the authority in the organization from the representative organs to the participatory channels.

Barber, Bookchin and Dahl have different takes on participatory democracy and the city, but share the view that proximity between residents and between residents and their government makes the city suited for a participatory form of government. Bookchin emphasizes, for example, that face-to-face encounters in the local communities of a city are the foundation for forums where common affairs can be discussed and decided upon among neighbors. Such forums are potentially open to all adult community members (Biehl 1998; Bookchin 2015; Bookchin 1995). The city is a public association. It favors public spaces and a vision of the city as a public common, and as such also a democratic culture derived from the close yet impersonal and free city life (Barber 2013, 68-71). Moreover, the relationship between citizens and the city government is more direct than with central governments. Whereas the government of the nation-state normally unfolds at a distance, the city administration regularly appears in the spaces where citizens convene (Barber 2013, 93). Although cities require experts and administration to solve their 
problems, these problems are fairly comprehensible to the average citizen (Dahl 1967, 967).

The state - both at the national/federal and the state/provincial level - is seen by city-democrats as too big to allow for extensive participation. Whenever the number of citizens grows large they must resort to representation. This eliminates the possibility that every citizen can engage in a discussion with the authorities. The channels of communication from the citizen to the top political leaders are long and indirect, and communication is asymmetrical. A leader of a state can speak directly to millions of voters, but only a tiny fraction can ever speak directly back (Dahl 1967, 957). The centralization of power creates a dynamic whereby citizens and communities are separated (Barber 1984, 248-249) and by which local public spheres are contained, controlled and manipulated by elites that are afraid to see their authority undermined (Bookchin 1995, 221). Instead of being active participants in politics, citizens become followers of leaders in representative institutions (Barber 1984, 224). That is why Barber does not ascribe much hope to attempts to democratize them. "On the whole," he writes, "attempts at democratization within the confines of thin democracy work only to further polarize elites and masses while cloaking oligarchic manipulation in a mantle of popular sovereignty" (Barber 1984, 206).

\section{An idealized image?}

A number of criticisms can be levelled against this view. One is that the city-democrats present an idealized image of the city; one not rooted in how cities actually work. Murray Low (2004), for example, argues that cities are far more complex than suggested above. Urban dwellers do not primarily interact with each other in neighborhoods, but in multiple settings that are not necessarily tied to the local community. Nor do they talk directly to each other or with the city government. Rather, their communication is mostly mediated by an array of technologies, institutions and organizations (2004, 133). Moreover, city inhabitants don't have uniform knowledge of the city's issues and its political affairs. Instead they have a lot of knowledge about some areas and very little about others, which means that their political competence varies. Barnett (2014) echoes this view and argues that the ideal of participatory democracy is not tied to a specific location. Sometimes the principle that everyone who is affected by a decision should 
have a say in it, leads groups of citizens to recognize themselves as affected by common urban issues, become organized through local public forums and to work directly with the city government in ways that are participatory and democratic. At other times, however, this principle might lead them to identify with citizens from other cities, become organized through representatives that build networks across cities, and to indirectly link up with governments and other institutions at a variety of scales. For Low it is not only wrong, but also dangerous, to view the city as a unique place for participatory democracy. It might lead us to overlook the potential for democratization in other settings, or even worse to underestimate the possibilities of democratizing governments and social relations at a larger scale $(2004,137)$.

The city-democrats concede that they present the image of an ideal city, but not that it is an idealized image of contemporary cities. Both Bookchin and Dahl use words such as 'non-city' or 'anti-city' to describe the modern megalopolis. They are more concerned with the democratic possibilities in the city, as opposed to those in state institutions at larger scales. But in order to realize this potential, the city's institutions and social life have to be reorganized and sometimes refashioned. Ultimately this is seen as part of a broader social transformation that deals with several structural impediments such as uncontrolled urban growth, the subversion of local autonomy by the state, entrenched political and economic elites and persistent social inequalities (Dahl 1990, 8996; Bookchin 1995; Barber 2013, chapter 7-9; Barber 1984, 251-260). This is why Bookchin and Barber argue that participatory democracy is best suited to smaller cities, and that today's megacities have the same problems as nation-states. Dahl places the number of inhabitants in an ideal democratic city as somewhere between 50,000 and 200,000 . This does not mean that participatory democracy has to be postponed until all cities are of this size. In large metropolises, for example, this ideal can be pursued by breaking it up into smaller administrative units. Political decentralization can open up democratic spaces at the neighborhood level while physical decentralization processes continue (Dahl 1967, 968-969; Bookchin 1995, chapter 8 and appendix). Nor do the city-democrats renounce political institutions at larger scales, but want to see them organized differently. Both Bookchin and Barber concede that this requires the election of representatives or 'delegates,' but they simultaneously believe that local participatory organs can sufficiently instruct and control these representatives and prevent them from 
ending up as self-serving elites (Bookchin 1995, appendix; Barber 1984, 248; Barber 2013, chapter 11) .

\section{Participatory budgeting in the city and the state}

It is not only Barber who sees participatory budgeting in Brazil - and especially in Porto Alegre - as an inspiring example of participatory democracy. It has a high-standing on the international Left, and been supported by development institutions such as the World Bank and the UN Development Program (Goldfrank 2012). Over the last decades, it has spread to more than a thousand cities worldwide - including places like New York, Paris and even municipalities in Scandinavia (Gilman 2016; Sintomer et al. 2016; Dias 2014). Although the ideal of participatory democracy is less visible in the various adaptations of participatory budgeting outside of Brazil, it was at the heart of the project when it was first initiated in Porto Alegre in 1989. The left-wing alliance led by the Workers' Party (PT) that won the elections in the city in 1988, saw it as a first step toward a socialist society based on an assembly- and council-structure emanating from the neighborhoods. One of the main aims was to break down the clientelism and corruption that had previously dominated the political life of the city, another was to direct public investments to the poorer city districts (Abers 2000, chapter 2-3; Baiocchi 2005, chapter 2).

The system has undergone various phases in Porto Alegre - from an early trial and error phase, to a period of stable growth with increasing popular support and improved administrative capacity, to a phase with a shrinking budget, reduced political support and increased debt problems (from around 2002-to date) (Abers 2000; Goldfrank 2011, chapter 5; Junge 2012; Chavez 2008). Yet the basic structure of the process has remained intact since the early 1990s. The money for the participatory budget is taken from the city's investment funds and is used to initiate new projects or services that range from connecting neighborhoods to the water network, paving roads, improving the sewer system, renovating schools, or establishing health clinics, computer labs and kindergartens etc. Secondly, the process has elements of both direct participation and representation. It begins in open assemblies in the city districts where residents can propose what kind of projects or services the budget should fund. Here, the participants also cast votes on which investment areas they want to prioritize, and they elect individ- 
uals to represent them at the city level. A similar process based on the thematic areas of the budget - such as education, infrastructure, transportation and health - also takes place. The task of the elected delegates is to knit together the proposals of the district and thematic assemblies, and to appoint the members of a budget council that write an investment proposition for the city in conjunction with the mayor's administration, based on the proposals and priorities decided through the participatory process. At the end of the budget cycle, the result of this work is delivered to the municipal legislative assembly which either alters the proposition or accepts it as it is.

Participatory budgeting has been adopted by hundreds of municipalities in Brazil (Avritzer and Vaz 2014; Fedozzi and Lima 2014). Still Porto Alegre is considered as one of the most successful examples of participatory budgeting, and the case that, at least in its stable growth phase, has been closest to the ideals of participatory democracy. ${ }^{24}$ Research finds that municipal autonomy and decentralization of fiscal authority (Goldfrank 2011), the willingness of the mayor's administration to delegate decisionmaking powers to the citizens (Wampler 2007) and civil society organizations that both cooperate and contest with the municipality (Baiocchi et al. 2011), are particularly favorable conditions for a participatory democratic budget process in the city. However, as Junge points out, Porto Alegre is far from a fully realized participatory democracy. Only a small percentage of citizens attend meetings - usually somewhere between 2-7 per cent of the total population. Many just show up at an assembly to vote, or even because they were told to do so by a community organization or municipal representative. They do not engage in sustained discussions, monitoring and mobilization over time. Participatory budgeting is also highly dependent on the goodwill of the mayor, who has a disproportionate power over the content of the process (Junge 2012, 421).

Participatory budgeting has also been adopted at the state level. In total five states have had a form of participatory budgeting. ${ }^{25}$ No other state has gone as far in imple-

\footnotetext{
${ }^{24}$ For comparisons of Porto Alegre with other Brazilian municipalities with participatory budgeting, see for example Wampler (2007); Baiocchi et al. (2011); Avritzer (2009); Marquetti et al. (2008) and Cabannes (2004).

${ }^{25}$ These are Mato Grosso do Sul (Bittar 2003), Rio de Janeiro (Peci 2000), Minas Gerais (Corrêa 2008), Paraíba (Cezário 2013) and Rio Grande do Sul. The share of states that have practiced participatory budgeting has actually been higher than that of municipalities. 2.8 per cent of all municipal governments (or government periods) since the early 1990s has done participatory budgeting, whereas the share is 4.9 per cent at the state level. I made this estimate by adding up the total number of municipal government periods from 1989-2002 based on the cur-
} 
menting it as Rio Grande do Sul. In 1999 the Workers' Party entered the government and initiated a process that aimed to create spaces where citizens could plan and decide on the budget, and to redistribute public funds to the poorest sectors of the population (Frente Popular 1998). All state investments were included in the participatory budget, but it was highly disputed and the government was forced to alter the organization of it due to pressures from the opposition (Goldfrank and Schneider 2006). It has continued to exist in the state since 1999, but in general right-wing governments have given the participatory budget a minor role in decisions over the state's investments. In 20112014 the Workers' Party regained power and tried to reinvigorate the process, but it only gave population the power to decide over about 10 per cent of the total investments. $^{26}$ The research on this process is less extensive than on Porto Alegre. However, Goldfrank and Schneider (2002) write that the existence and relative success of participatory budgeting at the state level challenges the assumption that participatory democracy is unworkable at large scales, although the regularity and the quality of participation seems to have been affected when moving from the city to the state level. Faria (2005) is concerned with how scale shifts power in the process from regular participants to representative forums, and that the bureaucracy is better organized and has a greater say in the process at the state level.

\section{Comparing 'best cases' at the city and state level}

I take this analysis a step further by adding data from the state participatory budget in Rio Grande do Sul 2011-2014. This data is from field-work I did in 2014, which consisted of interviews with government officials, organizers, participants and other central actors (49 interviews), observations of assemblies at the regional and local level ( 7 as-

rent number of municipalities in Brazil. For the number of government periods with participatory budgeting I used (Fedozzi and Lima 2014, 158) which give a total of number of 796 such periods. Some of these probably include participatory budgets that were started late or aborted, but that's also the case for the state level. The five states with participatory budgeting gives a total of 8 government periods from 1991-2014. I give Rio Grande do Sul four government periods with participatory budgeting. In addition to the state participatory budget from 1999-2002, I include all subsequent government periods since they involved a 'Consulta Popular' based on open municipal assemblies. This is a positive estimate since all of the state government periods would not fall into a strict definition of participatory budgeting. However, since there are good reasons to think that a large portion of the municipalities also would fall short of this definition, I believe this is a good comparison.

${ }^{26}$ Source: Transparência RS (www.transparencia.rs.gov.br). 
semblies), and a survey of delegates in a strategic selection of six of the state's 28 macro-regions (chosen to represent the demographic, economic, social and political diversity in the state). My description of participatory budgeting in Porto Alegre is based on secondary sources, ${ }^{27}$ but I also analyze raw survey data on delegates from 2003 and 2009. The description of the first period of the state participatory budget is also based on secondary sources. ${ }^{28}$ These secondary data highlight the development of the participatory budget over time, and give me an opportunity to compare the different levels. When using the secondary data, I have tried to be aware of possible bias, both positive and negative.

I compare what are considered the 'best cases' of participatory budgeting at the city and state level. The ideal here would be if these were also the most similar cases, in the sense that they were equal on all variables except for their scale (George and Bennett 2005, chapter 8; Levy 2008, 10-11). But they are not. The main similarities are that they were implemented and sustained by an alliance of a political party and social movements with commitments to participatory democracy and redistribution of public resources and that they are based on a similar organizational model. The main difference is that this alliance in Porto Alegre had more than 15 years to develop the process before the right-wing took over, whereas the state participatory budget had a shorter and more turbulent history of shifting governments and a contracting and expanding process. This study is based on both qualitative and quantitative data. I use this multimethod approach to be able to paint a more integrated picture of the participatory process, as opposed to only using one method. One weakness is that I have only surveyed delegates, and not regular participants in 2014. Since this comparison is about participatory democracy, I should ideally have data on the profile and opinions of both participants and delegates for all periods and at both levels. But despite these limitations, I think this study has more to gain than to lose from making a broad comparison.

\footnotetext{
${ }^{27}$ Especially the in-depth accounts and discussions in Baiocchi (2005); Abers (2000); Gret and Sintomer (2005); Avritzer (2009); Goldfrank (2011); Wampler (2007).

${ }^{28}$ These are Goldfrank and Schneider (2002); Goldfrank and Schneider (2006); Sobottka and Streck (2014); Goldfrank (2014); Streck et al. (2005); Faria (2005); (César 2004).
} 
Institutional design, representation and space for deliberation

City democrats claim the space for participation is smaller at the state than the city level, and that engagement will be more indirect and representative. My comparison supports this contention. Whereas the budget cycle in Porto Alegre is based on two rounds of open assemblies in the city's districts, the state participatory budget includes only one assembly meeting in each municipality. In the first round of assemblies in Porto Alegre the city administration presents the results of the previous year's budget, shows the available resources of the current year and answers critical questions from the audience. This kicks off an important phase of discussion and organization that goes on in the local communities until the next round of assemblies. In the second round of assemblies the investment proposals are made, budget priorities are voted on and delegates elected.

In the state participatory budget both these rounds take place within a time-frame of two to three hours in one meeting. Consequently, the space for discussion and critical questions is diminished. Another feature that used to be central to the participatory budget in Porto Alegre was thematic assemblies. These were meetings that took place on a city-wide basis where spending within the different sectors of the municipality was discussed. Nothing of this sort has been attempted at the state level. All in all, the state participatory budget has been characterized by a stripped-down model where the spaces of direct participation and deliberation are fewer.

Is this related to differences in scale? Both yes and no. Partly it is a question of resources. If the state government had enough personnel to travel around and encourage people to come to the meetings, it would probably be able to hold the same number of assemblies in each municipality as in Porto Alegre. But the state of Rio Grande do Sul does not have these resources. The process, however, does not only depend on logistical assistance, but also on the political legitimacy of the municipalities to implement the process at the local level. This is a question of scale. Rio Grande do Sul has nearly five hundred municipalities, many of which are small and dominated by politicians who do not favor participatory democracy. It is not realistic, therefore, to ask the municipalities to hold several rounds of assemblies. As one of the state organizers emphasized, a lot of convincing and negotiation have to take place in order for many municipalities to even host a single meeting: 
Even though [the state participatory budget] has been a tradition in Rio Grande do Sul for a long time, there are still places where local participation is small and timid [...]. Some mayors don't want to get involved in the process. If it was up to them it wouldn't take place. If they don't want to do it, we have to mobilize the community to force the municipality to get involved. But then the participatory process will be bad - if the municipal administration doesn't participate it will be very bad. So then the mayor says "ok, let's do it." Before we have to use our authority to ask other public sectors to get involved in the process, [the mayor and the municipal administration] normally come around to do it in partnership with us. But if it depended on their initiative, it wouldn't happen. ${ }^{29}$

This simplified model also means that the most important deliberation regarding the details of the budget is done by elected delegates. In the state-wide process from 19992002 this was especially the case as a state budget council was selected that wrote up, fairly autonomously, the final budget proposal. As Claudia Faria points out, the regular participants showing up at local assemblies in the state budgeting process are 'weak publics' compared to the 'strong publics' of the delegates where the elaboration of the budget takes place (Faria 2005, 204-206).

But this does not only happen at the state level. Also in Porto Alegre the delegates do most of the discussion, whereas the majority of participants only vote (Célérier and Botey 2015). However, at the local level there are opportunities for participants to control the delegates. First, the delegates live in the same neighborhood as the other participants. This makes it possible to bring up budget issues in everyday conversations. Second, meetings are held where delegates report back to the community on the workings of the budget process and the status of the local demands. Finally, neighborhood associations also rotate on who they elect as delegates, to prevent individuals from developing personal agendas and particular interests that are at odds with those who elected them (Baiocchi 2005, chapter 4; Wampler 2007, 77).

\footnotetext{
${ }^{29}$ Interview with "Rafael", Coordinator in the Office for Citizen Participation in the Department of Planning, Administration and Citizen Participation (Seplag) in the state government, 28.01.2014
} 
As Avritzer (2006) emphasizes, these practices are rooted in pre-existing participatory community traditions that are transmitted into the official public sphere. But is this only possible in the city? In general, there are three types of delegates in the state participatory budget. One is the mayor, local politician or municipal official. These delegates normally mobilize people from local communities and associations to come to the budget meetings, but do not respond to them. Next is the employee of a state institution like a school, hospital, fire brigade or police department. These delegates report back to the institutions and sometimes also to the users of the services they provide, such as pupils or patients. The last is the representative of a local community, a neighborhood association, social movement or NGO. These more frequently follow the same procedures as in Porto Alegre. One example is the Union of Resident Associations (UAM$\mathrm{CA}$ ) in Canoas, which is involved in both the municipal and the state participatory budget. As explained by one of UAMCAs leaders, who is also the leader of a neighborhood association, the mobilization and contact with local residents is interchangeable in the municipal and state participatory budget:

\begin{abstract}
We use online social networks, we call people on their phone, we are in touch with the president of the local associations and if it's needed we call a common meeting and then proceed to the communities. I have meetings with people in my community, for example, every first and third Saturday of the month, every month. So if we discuss something in the leadership we take it to the people in the community, because if not they would not be aware of it. ${ }^{30}$
\end{abstract}

\title{
Participation levels, type of participants and patterns of mobilization
}

Considering these reduced opportunities to take part in formulating the policies at the state level, one would expect that the participation rate would be lower at the state than at the municipal level. But that is not the case. In 2001 the relative share of the population attending the assemblies was higher at the state level (3.71 per cent $)^{31}$ than it has ever been in Porto Alegre (the highest was 1.27 per cent in 2002). ${ }^{32}$ The state participatory budget in 2011-2014, had lower assembly attendance than either of these two cases

\footnotetext{
${ }^{30}$ Interview with "Thais", delegate in the state participatory budget in Canoas, 10.04.2014

${ }^{31}$ Source: Goldfrank and Schneider (2002)

${ }^{32}$ Fedozzi et al. (2013)
} 
( 0.77 per cent). This is most likely caused by the fact the voting on the budget priorities was removed from the meetings and instead organized as a state-wide referendum. In 2014 approximately 1.3 million adults voted in this referendum, which makes up 11.7 per cent of the population. ${ }^{33}$

But who are these participants? Gret and Sintomer (2005) argue that the local scale of the Porto Alegre's participatory budget has made it possible for hitherto excluded groups to become involved in local politics. Thus, they also predict that the profile of the participants will be different in participatory processes at higher levels of government, since the issues at stake there will be more complex and detached from the everyday realities of the population. But here they seem to be wrong. A survey made of the participants at the state level in 1999-2002, shows that the majority had the same characteristic profile as in Porto Alegre; they were mostly women with low education and low incomes (César 2004; Coradini 2009). In other words, the enlarged scale of the process did not lead to elite-domination.

Table 1: Share of delegates with low education (up to primary education).

\begin{tabular}{lrr}
\hline & 2000(c)/2001(a) & 2009(d)/2014(b) \\
\hline $\begin{array}{l}\text { Delegates in the state participatory budget (from } \\
\text { the Metropolitan Region of Porto Alegre) }\end{array}$ & $46.4 \%$ & $19.8 \%$ \\
\hline $\begin{array}{l}\text { Delegates in the municipal participatory budget- } \\
\text { ing in Porto Alegre }\end{array}$ & $39 \%$ & $40.4 \%$ \\
\hline
\end{tabular}

Note: Based on closest possible comparison of delegates in time. The Metropolitan region of Porto Alegre consists of Porto Alegre and surrounding municipalities. However, most of the delegates in the metropolitan region are from Porto Alegre.

Sources: a) Faria $(2005,193)$ b) survey of delegates at state level in 2014 , conducted by the author c) Baiocchi $(2005,15)$ d) survey of delegates at the municipal level in Porto Alegre in 2009, conducted by Observatório da Cidade de Porto Alegre.

Unfortunately, we don't have data on the profile of regular participants in the state participatory budget from 2011-2014, but we do for the delegates. Delegates have always come from slightly more privileged sectors than the average participants (Fedozzi and Martins 2015; César 2004), so the interesting comparison here is not whether the delegates are different from assembly participants but whether they differ from each other at

\footnotetext{
${ }^{33}$ Sources for 2011-2014: http://www1.seplag.rs.gov.br/upload/Mensagem.pdf (last accessed $01.04 .2016)$
} 
the different levels. As shown in table 1 nearly half of the delegates at the state level (46.4 per cent) came from lower-educated sectors of the population in the early $2000 \mathrm{~s}$, whereas this was the case of 39 per cent in Porto Alegre. Around the time of the second state participatory budget their profiles were very different. The share of delegates with low education was still high in Porto Alegre (40 per cent), but it was only 19.8 per cent among state delegates.

This table shows that the profile of delegates (and most probably therefore the sectors taking part in the process) is not dependent on the scale, but rather on other factors. The most probable explanation for the gap that has developed in recent years is that social movements, unions and neighborhood associations do not involve themselves in the state participatory process and therefore do not mobilize the low-income sectors to participate anymore. The community connected delegate has become the minority. As a study of state participatory budgeting in both the early 2000s and in recent years read: "[In] the original experiences participating citizens came mainly from what me might call civil society: people who came on their own, who became mobilized by neighborhood initiatives, or were participants in social movements, trade unions or other civil organisations. [...] [Now] more than half of the participants in public meetings of the participatory budgeting process are public servants" (Sobottka and Streck 2014, 169). My survey confirms this picture. Most delegates in 2014 were employed by the government. 67 per cent said that they represented a municipality, a state organ or a hospital, school or university, and only 18 per cent represented a civil society association, NGO, social movement, popular council or trade union. In comparison, the survey from 2001 shows 54 per cent of the state delegates in the metropolitan region at that time participated in a neighborhood association, 14.5 per cent in a trade union, 14.7 per cent in a popular council, and 9 per cent in an NGO (Faria 2005, 177).

\section{Comprehensibility, bureaucratic administration and popular control}

One of the reasons that participatory democracy is assumed to work better at the city level, is that the context is more comprehensible for ordinary citizens. Gret and Sintomer (2005) argue that higher scales will require more socio-economic resources of the participants, because it is more difficult to understand the complexity of the process when it encompasses more people. One indicator of such comprehension could be the 
familiarity the participants have with the rules that guide the process. Again, what I have done is a comparison of the delegates' familiarity and not ordinary participants. But if their hypothesis is right we should probably see the same pattern among delegates as well, since this group would also struggle with more complexity at larger scales.

Table 2: Linear probability model: degree of familiarity with the rules and regulations of the participatory budget process (few or none vs. most or some) among delegates in Porto Alegre 2009 and Rio Grande do Sul 2014.

\begin{tabular}{|c|c|c|c|}
\hline & Municipal delegates & State delegates & T-test comparison \\
\hline \multicolumn{4}{|l|}{ Gender } \\
\hline \multicolumn{4}{|c|}{ Women (reference group) } \\
\hline Men & $-0.17(0.07)^{\star}$ & $0.17(0.04)^{\star \star}$ & -3.93 \\
\hline \multicolumn{4}{|l|}{ Age } \\
\hline \multicolumn{4}{|c|}{$\begin{array}{l}\text { Less than } 26 \text { years (refer- } \\
\text { ence group) }\end{array}$} \\
\hline $26-41$ years & $0.28(0.21)$ & $-0.06(0.08)$ & 1.51 \\
\hline $42-60$ years & $0.33(0.20)$ & $0.10(0.07)$ & 1.05 \\
\hline More than 60 years & $0.43(0.03) \dagger$ & $0.11(0.09)$ & 1.29 \\
\hline \multicolumn{4}{|l|}{ Education } \\
\hline \multicolumn{4}{|c|}{$\begin{array}{l}\text { No complete formal edu- } \\
\text { cation (reference group) }\end{array}$} \\
\hline Primary education & $0.11(0.12)$ & $0.09(0.11)$ & 0.09 \\
\hline Secondary education & $0.39(0.10)^{\star \star}$ & $0.20(0.10)^{*}$ & 1.31 \\
\hline Higher education & $0.48(0.13)^{\star \star}$ & $0.34(0.10)^{\star \star}$ & 0.89 \\
\hline \multicolumn{4}{|l|}{ Employment situation } \\
\hline \multicolumn{4}{|c|}{$\begin{array}{l}\text { Precarious employment } \\
\text { or out of work (reference } \\
\text { group) }\end{array}$} \\
\hline Stable employment & $0.05(0.08) \dagger$ & $0.12(0.06)^{*}$ & -0.68 \\
\hline Constant & $0.11(0.22)$ & $0.12(0.12)$ & \\
\hline F-statistic & $4.23^{\star \star}$ & $7.16^{\star *}$ & \\
\hline Adjusted $\mathrm{R}^{2}$ & 0.15 & 0.08 & \\
\hline $\mathrm{N}$ & 146 & 557 & \\
\hline \multicolumn{4}{|c|}{$\begin{array}{l}\text { Note: The coefficients are unstandardized regression coefficients with standard errors in paren- } \\
\text { thesis. Significance levels: }{ }^{\star \star} p<0,01 ;{ }^{*} p<0,05 ; \mathrm{p}<0,10 \text {. The t-test of the regression coefficients } \\
\text { in the two models shows that they are not significantly different from each other at the munici- } \\
\text { pal and state level. Following Mood (2010) I have opted for a linear probability model even } \\
\text { though the dependent variable is dichotomous. This is because logistic regression is vulnerable } \\
\text { to unobserved heterogeneity and cannot be compared across samples. However, I have run a } \\
\text { logistic regression as a robustness check, and both methods give similar results. }\end{array}$} \\
\hline
\end{tabular}


As the linear probability model in table 2 shows there is a correlation between educational resources and the economic resources that come from being in a stable employment situation at both levels. The correlation between the length of the education and familiarity of rules, however, is not stronger at the state level. This contradicts the prediction made by Gret and Sintomer. The probability that delegates with secondary education as compared to delegates with no complete formal education will understand the rules of the process is higher at the municipal (0.39) than at the state level $(0.20)$. The probability that delegates with higher education will know them as opposed to those with no education is also higher at the municipal (0.48) than the state level $(0.34)$. The difference between these coefficients, however, is not statistically significant. We cannot conclude that the process is more difficult to understand at the city level for people with lower education. This finding is somewhat surprising, but it's probably due to the fact that the participatory budget is a quite complex process in Porto Alegre. Nevertheless, this finding at least disturbs the notion that it is much easier to understand the workings of urban rather than state affairs.

Another assumption made is that as the complexity of issues increases at higher scales, experts and bureaucratic organizations will be more dominant in the decisionmaking processes. The participatory budget in Rio Grande do Sul exhibits an ongoing tension between the regular participants and staff in the state departments. Participants complain about the little degree of freedom they have in choosing the investments that they really want, whereas employees in the bureaucracy complain about the shortsightedness and ignorance of long-term planning, service delivery and infrastructure development among participants. There have been attempts to alleviate this tension. The organizers try, for example, to have officials from relevant state departments present at public assemblies to answer questions from the public as well as to provide information on the realism of different local demands. But the outcome of this has been ambiguous. On the one hand it has probably helped reduce the distance between the state administration and the population. On the other hand, it seems to have had the unintended consequence that these bureaucrats involve themselves in the process and try to convince participants to vote in favor of the demands of their sector. 
Faria (2005) argues that state bureaucracies are larger and also more autonomous than at the local scale, and that this gives them more power vis-à-vis citizens in Rio Grande do Sul than in Porto Alegre. But this is also prevalent at the city level. As Rebecca Abers writes, the government in Porto Alegre "publicly declared that all budget decisions were 'approved by the [elected council in the budget process].' But in practice, it had significant influence over the results of many of the council's decisions. Not only did the administration have a monopoly on information about government practices, but also government staff included highly skilled professionals who were nearly always capable of formulating convincing arguments" (Abers 2000, 200).

It is difficult to measure whether this tension favors more the bureaucracy or the participants at the state and the municipal level, but if we are to judge based on the delegates' own perception of their influence they are more positive in Porto Alegre than at the state level. When asked about their influence to establish the rules and guidelines that regulate the process, almost 50 per cent of the delegates in Porto Alegre said that they always have this authority whereas 30 per cent of the delegates in Rio Grande do Sul thought the same. When asked to evaluate their authority to monitor the implementation of projects selected through participatory budgeting, 71 per cent of the delegates in Porto Alegre said that they always had such authority compared to 53 per cent of the delegates in Rio Grande do Sul. ${ }^{34}$

\section{Is Barber's hope warranted?}

Barber writes that participatory budgeting offers hope for those who believe there may be a little less distance between mayors and citizens than between voters and state authorities. This study only partly warrants this hope. Participatory budgeting may remain closer to the ideals of participatory democracy when it occurs at the city level, but this does not imply that participatory democracy is impossible at larger scales. The state participatory budget has limitations: the space for deliberation among participants is narrow, the process is more representative than direct, and the state bureaucracy tries to

\footnotetext{
${ }^{34}$ Thanks to Brian Wampler for giving me access to the survey he did of a random selection of around half the delegates in Porto Alegre in 2003. Beware that the delegates' perception of their own authority may not only vary with scale, but also time. It is not unproblematic to compare a survey done in 2003 and in 2014.
} 
influence the outcome. This description is also valid for Porto Alegre, but to a lesser degree.

Does this mean that Low is right in that there is nothing special about the city? I think this conclusion would also be wrong. One of the key characteristics of democratic participation has been the existence community-based associations that have mobilized participants form low income sectors and introduced new relations between delegates and participants into the budget process. For a time this was recreated in the state participatory budget, and when these associations stopped mobilizing at the state level, the process became dominated by public officials and participants from more privileged backgrounds.

As Barber writes, participatory budgeting in Brazil is just one of many cases that cannot by themselves prove or disprove the proposition that the city is the most appropriate scale for participatory democracy. This picture would also be different if we broadened our scope to examine the space for participatory processes at the nation-state level - the realm of 'big politics'; of monetary and foreign policy and of law-making. Nevertheless, the experiences of participatory budgeting in Brazil suggest that it is both wrong to overemphasize the uniqueness of the city and to undervalue the special role the city might play in larger, as well as local, participatory processes.

\section{Literature}

Abers, R. N. 2000, Inventing Local Democracy: Grassroots Politics in Brazil, London, Lynne Rienner Publishers.

Avritzer, L. 2006. 'New Public Spheres in Brazil: Local Democracy and Deliberative Politics'. International Journal of Urban and Regional Research, vol. 30, no. 3, pp. 623-637.

Avritzer, L. 2009, Participatory Institutions in Democratic Brazil, Baltimore, The John Hopkins University Press.

Avritzer, L. \& Vaz, A. N. 2014. 'The Emergence of the Participatory Budget and Its Expansion in Brasil: Analysing the Potential and Limitations', in Dias, N. (ed.) Hope for Democracy: 25 Years of Participatory Budgeting Worldwide, São Brás de Alportel, In Loco Association.

Bachrach, P. \& Botwinick, A. 1992, Power and Empowerment : A Radical Theory of Participatory Democracy, Philadelphia, Temple University Press. 
Baiocchi, G. 2005, Militants and Citizens: The Politics of Participatory Democracy in Porto Alegre, Standford, Standford University Press.

Baiocchi, G., Heller, P. \& Silva, M. K. 2011, Bootstrapping Democracy: Transforming Local Governance and Civil Society in Brazil, Standford, Standford University Press.

Barber, B. R. 1984, Strong Democracy : Participatory Politics for a New Age, Berkeley, University of California Press.

Barber, B. R. 2013, If Mayors Ruled the World: Dysfunctional Nations, Rising Cities, New Haven, Yale University Press.

Barnett, C. 2014. 'What Do Cities Have to Do with Democracy?'. International Journal of Urban and Regional Research, vol. 38, no. 5, pp. 1625-1643.

Biehl, J. 1998, The Politics of Social Ecology: Libertarian Municipalism, Montreal, Black Rose Books.

Bittar, J. (ed.) 2003. Governos Estaduais - Desafios e Avanços: Reflexões e Relatos de Experiências Petistas, São Paulo: Editora Fundação Perseu Abramo.

Bookchin, M. 1995, From Urbanization to Cities: Toward a New Politics of Citizenship, London, Cassell.

Bookchin, M. 2015, The Next Revolution: Popular Assemblies and the Promise of Direct Democracy, New York, Verso Books.

Cabannes, Y. 2004. 'Participatory Budgeting: A Significant Contribution to Participatory Democracy'. Environment and Urbanization, vol. 16, no. 1, pp. 27-46.

Célérier, L. \& Botey, L. E. C. 2015. 'Participatory Budgeting at a Community Level in Porto Alegre: A Bourdieusian Interpretation'. Accounting, Auditing \& Accountability Journal, vol. 28, no. 5, pp. 739-772.

César, B. T. 2004. Orçamento Participativo Estadual: Perfil Social e Político de seus Participantes. VIII Congresso Luso-Afro-Brasileiro de Ciências Sociais. Coimbra, Portugal.

Cezário, G. D. A. 2013. A Democratização da Administração Pública: A Experiência do Orçamento Democrático Estadual e a Gestão Participativa. Bachelor, Universidade Edstadual da Paraíba.

Chavez, D. 2008. 'The Watering Down of Participatory Budgeting and People Power in Porto Alegre, Brazil'. Participatory Learning and Action, vol., no. 58, pp. 57-60.

Coradini, O. L. 2009. 'Conceptions de "Participation" et de Militantisme Dans le Budget Participatif de L'état du Rio Grande do Sul (1999-2002)'. Cahiers du Brésil Contemporain, vol., no. 73/74, pp. 201-228.

Corrêa, I. M. 2008. 'Entre a Representação e a Participação: Coordenação e Competição na Implementação da Participação Popular no Ciclo Orçamentário em Belo Horizonte e em Minas Gerais'. Teoria \& Sociedade, vol. 2, no. 16, pp. 34-71.

Dahl, R. A. 1967. 'The City in the Future of Democracy'. The American Political Science Review, vol. 61, no. 4, pp. 953-970.

Dahl, R. A. 1990, After the Revolution? : Authority in a Good Society, New Haven, Yale University Press. 
Dahl, R. A. \& Tufte, E. R. 1973, Size and Democracy, Stanford, Stanford University Press.

Della Porta, D. 2013, Can Democracy Be Saved?, Cambridge, Polity Press.

Dias, N. (ed.) 2014. Hope for Democracy: 25 Years of Participatory Budgeting Worldwide, São Brás de Alportel: In Loco Association.

Faria, C. F. 2005. O Estado em Moviemento: Complexidade Social e Participação Política No Rio Grande Do Sul. PhD, Universidade Federal de Minas Gerais.

Fedozzi, L. J., Furtado, A., Bassani, V. D. S., Macedo, C. E. G., Parenza, C. T. \& Cruz, M. 2013, Orçamento Participativo de Porto Alegre: Perfil, Avaliação e Percepções do Público Participante, Porto Alegre, Gráfica e Editora Hartmann.

Fedozzi, L. J. \& Lima, K. C. P. L. 2014. 'Participatory Budgets in Brazil', in Dias, N. (ed.) Hope for Democracy: 25 Years of Participatory Budgeting Worldwide, São Brás de Alportel, In Loco Association.

Fedozzi, L. J. \& Martins, A. L. B. 2015. 'Trajetória do Orçamento Participativo de Porto Alegre: Representação d Elitização Política'. Lua Nova, vol., no. 95, pp. 181-225.

Frente Popular 1998. Proposta de Governa da Frente Popular: Candidatura Olívio Dutra. Rio Grande do sul.

Fung, A. 2011. 'Reinventing Democracy in Latin America'. Perspectives on Politics, vol. 9, no. 04, pp. 857-871.

George, A. L. \& Bennett, A. 2005, Case Studies and Theory Development in the Social Sciences, Cambridge, Massachusetts, MIT Press.

Gilman, H. R. 2016, Democracy Reinvented: Participatory Budgeting and Civic Innovation in America, Washington, D.C., Brookings Institution Press.

Goldfrank, B. 2011, Deepening Local Democracy in Latin America: Participation, Decentralization, and the Left, University Park, PA, Penn State University Press.

Goldfrank, B. 2012. 'The World Bank and the Globalization of Participatory Budgeting'. Journal of Public Deliberation, vol. 8, no. 2, pp.

Goldfrank, B. 2014. Participation, Distribution, and the Left: The Return of PB in Rio Grande Do Sul. A New Critical Juncture? Changing Patterns of Representation and Regime Politics in Contemporary Latin America. Kellogg Institute, University of Notre Dame.

Goldfrank, B. \& Schneider, A. 2002. Budgets and Ballots in Brazil: Participatory Budgeting from the City to the State. IDS Working Paper. Sussex: Institute for Development Studies.

Goldfrank, B. \& Schneider, A. 2006. 'Competitive Institution Building: The PT and Participatory Budgeting in Rio Grande do Sul'. Latin American Politics and Society, vol. 48, no. 3, pp. 1-31.

Gret, M. \& Sintomer, Y. 2005, The Porto Alegre Experiment: Learning Lessons for Better Democracy, London, Zed Books.

Junge, B. 2012. 'NGOs as Shadow Pseudopublics: Grassroots Community Leaders' Perceptions of Change and Continuity in Porto Alegre, Brazil'. American Ethnologist, vol. 39, no. 2, pp. 407-424. 
Levy, J. S. 2008. 'Case Studies: Types, Designs, and Logics of Inference'. Conflict Management and Peace Science, vol. 25, no. 1, pp. 1-18.

Low, M. 2004. 'Cities as Spaces of Democracy: Complexity, Scale and Governance', in Barnett, C. \& Low, M. (eds.) Spaces of Democracy: Geographical Perspectives on Citizenship, Participation and Representation, London, SAGE Publications Ltd.

Mansbridge, J. J. 1983, Beyond Adversary Democracy, Chicago, The University of Chicago Press.

Marquetti, A., Campos, G. a. D. \& Pires, R. (eds.) 2008. Democracia Participativa e Redistribuição: Análise de Experiências de Orçamento Participativo, São Paulo: Xamã.

Mood, C. 2010. 'Logistic Regression: Why We Cannot Do What We Think We Can Do, and What We Can Do About It'. European Sociological Review, vol. 26, no. 1, pp. 67-82.

Pateman, C. 1970, Participation and Democratic Theory, Cambridge, Cambridge University Press.

Pateman, C. 2012. 'Participatory Democracy Revisited'. Perspectives on Politics, vol. 10, no. 01, pp. 7-19.

Peci, A. 2000, Orçamento Participativo Estadual: Análise da Experiência do Rio de Janeiro, Rio de Janeiro, Associação Nacional de Pós-Graduação e Pesquisa em Administração (ANPAD).

Sintomer, Y., Röcke, A. \& Herzberg, C. 2016, Participatory Budgeting in Europe: Democracy and Public Governance, New York, Routledge.

Sobottka, E. A. \& Streck, D. R. 2014. 'When Local Participatory Budgeting Turns into a Participatory System: Challenges of Expanding a Local Democratic Experience'. International Journal of Action Research, vol. 10, no. 2, pp. 156-183.

Streck, D. R., Eggert, E. \& Sobottka, E. A. (eds.) 2005. Dizer a Sua Palavra: Educação Cidadã, Pesquisa Participante, Orçamento Público, Pelotas: Seiva Publicações.

Thacher, D. 2006. 'The Normative Case Study'. American Journal of Sociology, vol. 111, no. 6, pp. 1631-1676.

Wampler, B. 2007, Participatory Budgeting in Brazil: Contestation, Cooperation and Accountability, University Park, The Pennsylvania State University Press.

Wright, E. O. 2010, Envisioning Real Utopias, London, Verso. 